Rev. Col. Bras. Cir.

\title{
SOBRE OS CONGRESSOS REGIONAIS ...
}

\section{ABOUT THE REGIONAL CONGRESSES...}

O Colégio Brasileiro de Cirurgiões encontrou, na organização de congressos vinculados às suas seis Vice-Presidências Setoriais, uma forma de expandir a divulgação das novidades e avanços da cirurgia, além de valorizar os seus membros espalhados por todo o Brasil.

No ano 2000, o Diretório Nacional acrescentou às suas atividades científicas obrigatórias a organização desses Congressos Regionais, juntando-os aos já existentes do Núcleo Central e do Capítulo de São Paulo.

Estes congressos passaram a ocorrer a cada dois anos de forma alternada com o Congresso Brasileiro de Cirurgia.

A experiência adquirida aliada ao sucesso dos já existentes Congressos do Núcleo Central e da Assembléia Médica do Capítulo de São Paulo serviu de modelo para a implantação dos Congressos.

Os seis Setores do CBC foram divididos em dois grupos e a cada dois anos alternadamente se juntam ao Núcleo Central e ao Capítulo de São Paulo no cumprimento do que determina o Regimento Interno.

É uma regra regimentar que em cada Setor deve haver um rodízio na representatividade através dos capítulos que o constituem.

Este ano, o Setor II formado pelos capítulos do Maranhão, Piauí e Ceará, terá como Sede do Congresso o Capítulo do Ceará; o Setor V composto por Mato Groso, Mato Grosso do Sul, Goiás, Tocantins e Distrito Federal serão representados por Mato Grosso e o Setor VI que além de São Paulo com posição cativa terá Santa Catarina representando os demais Capítulos que o completam: Paraná e Rio Grande do Sul.

\section{Armando de Oliveira e Silva, TCBC \\ $1^{\circ}$ Vice-Presidente do $C B C$}

Os temas centrais dos diversos Congressos serão:

- Núcleo Central: Novas Fronteiras em Cirurgia - de 10 a 12 de agosto no Rio de Janeiro;

- Capítulo de São Paulo: Avanços, Técnicas e Complicações - 06 e 07 de outubro em São Paulo;

- Setor II: Desafios em Cirurgia - de 16 a 18 a novembro em Fortaleza;

- Setor V: Fronteiras da Cirurgia - de 26 a 28 de outubro em Cuiabá;

- Setor VI: Temas Gerais de Cirurgia - de 18 a 21 de outubro em Blumenau.

O Regimento Interno do Colégio Brasileiro de Cirurgiões nos capítulos 7 e 7.2, regulariza Congressos / Jornadas Regionais de Cirurgia do artigo 132 ao 137, estabelecendo as normas de como devem os Congressos Regionais serem organizados. Cabe ao Diretório Nacional através do seu $1^{\circ}$ VicePresidente a Coordenação-Geral.

Esta Coordenação entende que estes Congressos devem ter um perfil regionalista com participação ativa dos membros dos diversos capítulos do setor.

Nos Congressos deste ano, o atual Diretório Nacional espera confirmar o êxito alcançado nos anos anteriores onde a riqueza de ensinamentos e a possibilidade de confraternização entre os membros do Colégio Brasileiro de Cirurgiões seja a meta a ser alcançada. 